International Business and Global Economy 2017, no. 36, pp. 144-156

Biznes międzynarodowy w gospodarce globalnej 2017, nr 36, s. 144-156

Edited by the Institute of International Business, University of Gdańsk

ISSN 2300-6102

e-ISSN 2353-9496

DOI 10.4467/23539496IB.17.010.7458

\title{
Tendencje w rozwoju polskich bezpośrednich inwestycji zagranicznych kierowanych do sektora usług
}

Celem artykułu jest prezentacja wyników analizy zmierzającej do zidentyfikowania głównych tendencji rozwoju polskich BIZ kierowanych do sektora usług, a w szczególności zmian strukturalnych w obrębie tych inwestycji oraz wykorzystania BIZ przez polskie przedsiębiorstwa w celu optymalizacji obciążeń fiskalnych. Badania przeprowadzono głównie w oparciu o dane statystyczne NBP, Eurostatu i UNCTAD. Z badań wynika, że znaczenie sektora usług dla aktywności inwestycyjnej polskich przedsiębiorstw jest obecnie duże, co pozostaje $\mathrm{w}$ zgodzie $\mathrm{z}$ trendami światowymi. W strukturze branżowej tych inwestycji dominuje działalność holdingów, co jednocześnie przy ich geograficznym skoncentrowaniu w centrach finansowych jednoznacznie wskazuje na cel tej aktywności, którym jest wykorzystanie międzynarodowych mechanizmów optymalizacji podatkowej. Zjawisko to nie dotyczy tylko polskich przedsiębiorstw znajdujących się pod kontrolą kapitału zagranicznego, ale także podmiotów kontrolowanych przez rezydentów. Nasilenie procesu optymalizacji fiskalnej dzięki wykorzystaniu podmiotów bezpośredniego inwestowania zauważalne jest zwłaszcza w ostatnich kilku latach.

Słowa kluczowe: polskie inwestycje bezpośrednie, bezpośrednie inwestycje zagraniczne, usługi, ekspansja inwestycyjna, optymalizacja fiskalna

Klasyfikacja JEL: F21, F23

\section{Trends in Polish foreign direct investment targeted at the service sector}

The aim of this article is to examine the trends in Polish FDI targeted at the service sector, paying particular attention to the structural changes within the FDI and their deployment for tax optimisation. The research was based on statistical data from Narodowy Bank Polski (Central Bank of Poland), EUROSTAT, and UNCTAD. The research shows the growing importance of the service sector in Polish FDI. This is consistent with general FDI trends. The industry structure of Polish FDI is dominated by holding companies geographically concentrated in offshore financial centres. This indicates that the aim of their activities is to use transnational mechanisms to optimise the tax burden. This phenomenon applies to Polish companies controlled by both foreign and domestic capital. An intensification of the process of fiscal optimisation by use of offshore subsidiary companies has been particularly noticeable in recent years.

Keywords: Polish OFDI, foreign direct investment, services, investment expansion, fiscal optimisation

JEL classification: F21, F23 


\section{Wprowadzenie}

Jeszcze do niedawna Polska była przede wszystkim importerem bezpośrednich kapitałów inwestycyjnych. Jednak wraz z rozwojem gospodarczym Polski zwiększał się stopień ekspansji zagranicznej polskich przedsiębiorstw w najbardziej zaawansowanej formie bezpośrednich inwestycji zagranicznych. W analizie kształtowania się BIZ wypływających z Polski i napływających do niej badacze wykorzystują koncepcję ścieżki rozwoju inwestycji IDP (Investment Development Path - IDP) opracowaną przez Johna Dunninga [Dunning, 1981; Dunning, 1986; Dunning, Narula, 2002]. W koncepcji tej występuje 5 faz rozwoju gospodarki, które korespondują z poziomem napływu i wypływu BIZ. Z przeprowadzonych dotychczas badań wynika, że Polska znajduje się w momencie przejściowym z fazy 2 do 3 [Gorynia, Nowak, Wolniak, 2009; Gorynia, Nowak, Wolniak, 2010a; Gorynia, Nowak, Wolniak, 2010b; Gorynia, Nowak, Wolniak, 2012; Radło, Sass, 2012]. Faza ta charakteryzuje się tym, że kraj w coraz większym stopniu staje się eksporterem kapitałów bezpośredniego inwestowania, a tempo spadku wskaźnika NOIP (Net Outward Investment Position), który stanowi różnicę między wypływającymi a napływającymi zasobami BIZ, zostaje spowolnione.

Wzrost aktywności polskich przedsiębiorstw jako bezpośrednich inwestorów na rynkach zagranicznych uzasadnia pogłębione badania tego zjawiska.

Celem artykułu jest prezentacja wyników analizy zmierzającej do zidentyfikowania głównych tendencji rozwoju polskich BIZ kierowanych do sektora usług, a w szczególności zmian strukturalnych w obrębie tych inwestycji oraz wykorzystania BIZ przez polskie przedsiębiorstwa w celu optymalizacji obciążeń fiskalnych. Badania przeprowadzono głównie w oparciu o dane statystyczne NBP, Eurostatu i UNCTAD. Ze względu na to, że UNCTAD do trzeciego sektora zalicza także działalność związaną z wytwarzaniem i dostawą energii, gazu oraz wody, a także budownictwo, w celu zapewnienia porównywalności danych globalnych i polskich do sektora usług w przypadku analizy polskich BIZ także włączono wspomniane branże. Podkreślenia wymaga jednak to, że wyłączenie ich z sektorowej analizy polskich BIZ nie ma istotnego wpływu na wnioski wynikające z przeprowadzonej analizy.

\section{Znaczenie sektora usług w bezpośrednich inwestycjach zagranicznych na świecie}

Od połowy lat osiemdziesiątych rośnie na świecie zaangażowanie przedsiębiorstw w zagraniczne inwestycje bezpośrednie w sektorze usług. O ile jeszcze na 
początku lat siedemdziesiątych udział zobowiązań z tytułu BIZ w przedsięwzięcia usługowe wynosił około $25 \%$, to w kolejnych latach stopniowo rósł, osiągając w 2012 r. poziom 63\%. Obserwowany trend był zbieżny z rosnącym znaczeniem usług $\mathrm{w}$ gospodarce na przestrzeni kilku ostatnich dziesięcioleci.

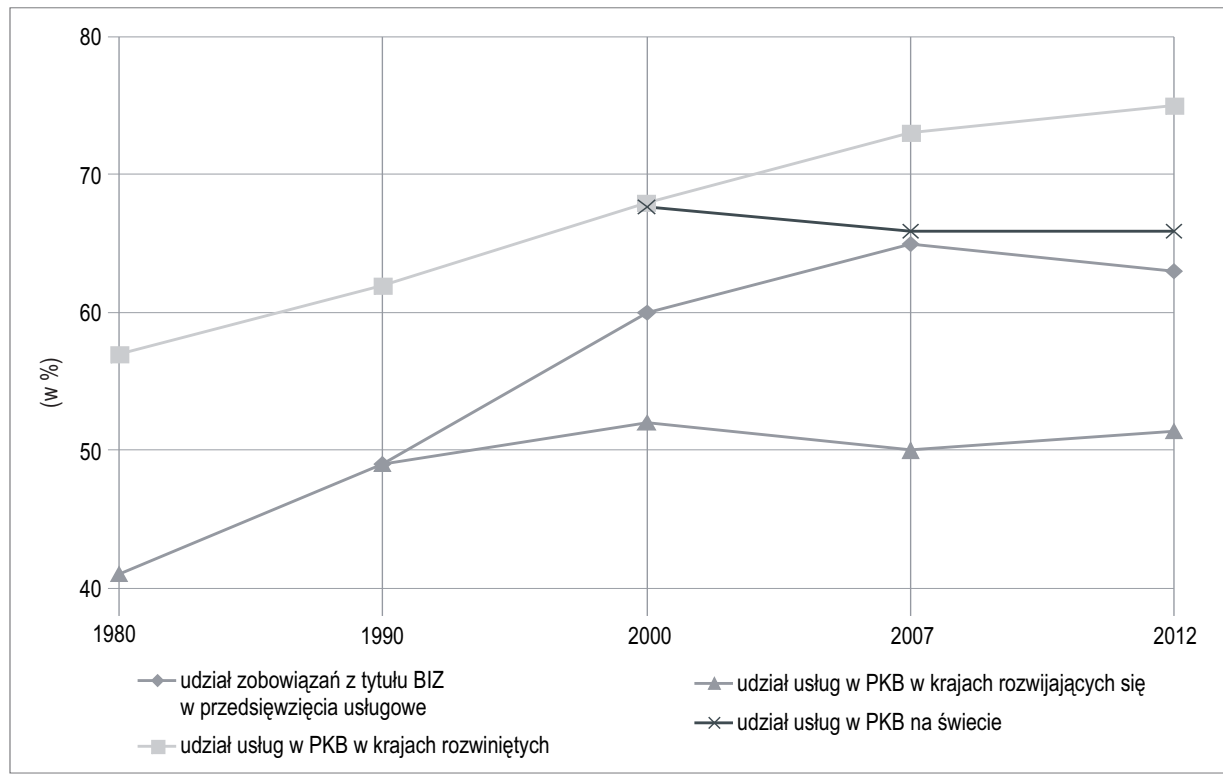

* Dla udziału usług w PKB na świecie w 2007 r. podano dane za 2008 r.

Rysunek 1. Udział usług w BIZ i w PKB na świecie

Źródło: Opracowanie własne na podstawie: [UNCTAD, 2002; UNCTAD, 2004; UNCTAD, 2009a; UNCTAD, 2009b; UNCTAD, 2014; UNCTAD, 2015].

Jak wynika jednak z danych przedstawionych na rysunku 1, udział sektora usług $\mathrm{w}$ zagranicznej ekspansji inwestycyjnej przedsiębiorstw rósł z pewnym opóźnieniem w stosunku do wzrostu udziału tego sektora w PKB. Wzrost BIZ $\mathrm{w}$ branżach usługowych hamowany był bowiem przez wiele lat przez funkcjonujące $w$ większości gospodarek systemy ochrony wewnętrznych rynków usługowych oraz monopolistyczną lub oligopolistyczną strukturę rynku niektórych usług. Rozpoczęty w drugiej dekadzie lat osiemdziesiątych i kontynuowany w latach dziewięćdziesiątych $X X$ w. proces deregulacji sektora usług, liberalizacja polityki dotyczącej zagranicznych, bezpośrednich przepływów kapitałowych m.in. do trzeciego sektora oraz procesy prywatyzacyjne i znoszenie monopoli państwowych $\mathrm{w}$ wielu gospodarkach dynamizowały napływ BIZ do sektora usług [UNCTAD, 1994; UNCTAD, 2004; UNCTAD, 2009a; UNCTAD, 2015]. 
Trend wzmacniało nasilające się zjawisko offshoringu procesów biznesowych, w tym przenoszenie za granicę procesów usługowych przedsiębiorstwa, takich jak: księgowość, finanse, usługi informatyczne i programistyczne, biura obsługi klientów, działalność badawczo-rozwojowa. Tak dynamiczny rozwój offshoringu spowodowany był zarówno zmniejszaniem barier dostępu do rynku usług, jak i zmianami technologicznymi związanymi z cyfryzacją gospodarek. Rozwój technologii informacyjno-komunikacyjnych oraz obniżenie kosztów digitalizacji i przesyłu informacji umożliwiły standaryzację i cyfryzację wielu usług, co pozwoliło przedsiębiorstwom na rozdzielenie produkcji i konsumpcji usług (w wielu przypadkach dotychczas niemożliwe), a w konsekwencji wydzielenie funkcji usługowych i przesuwanie ich poza granice kraju. Odzwierciedleniem tego zjawiska są liczne centra usług wspólnych (Shared Service Centres SSCs), centra outsourcingu procesów biznesowych (Business Process Outsourcing - BPO) czy centra badawczo-rozwojowe, lokalizowane nie tylko w krajach Zachodu, ale także w Azji, Ameryce Środkowej i Południowej oraz Europie Środkowo-Wschodniej [WTO, 2005; UNCTAD, 2004; Gereffi, Fernandez-Stark, 2010].

Analizując zagraniczne bezpośrednie przepływy kapitałowe, należy jednak pamiętać o zjawiskach, które mogą zniekształcać obraz BIZ w trzecim sektorze. Należą do nich np. inwestycje kierowane do rajów podatkowych i centrów finansowych, których faktycznym celem jest optymalizacja podatkowa. Korporacje międzynarodowe inwestują $\mathrm{w}$ tych krajach $\mathrm{w}$ jednostki rejestrowane jako holdingi, których działalność ograniczona jest tylko do kontrolowania finansowych aktywów w innych spółkach i nie obejmuje zarządzania nimi (działalność holdingów finansowych), albo w holdingi zajmujące się kontrolowaniem i zarządzaniem innymi jednostkami korporacji (działalność firm centralnych i holdingów). Po przekazaniu kapitałów bezpośredniego inwestowania do spółki holdingowej, której działalność klasyfikowana jest jako usługowa, transferowane są one następnie do innych krajów, a także do innych sektorów wytwórczych.

Zjawisko to nie dotyczy jedynie rajów podatkowych i centrów finansowych. Struktury holdingowe wykorzystywane są przez korporacje międzynarodowe nie tylko w celach optymalizacji podatkowej. Proces ten zniekształca zatem dane o sektorowej i geograficznej strukturze bezpośrednich inwestycji zagranicznych. O skali tego zjawiska świadczą dane UNCTAD. Według szacunków tego organu ONZ w 2012 r. 30\% zobowiązań z tytułu BIZ zlokalizowanych w krajach niezaliczanych do finansowych centrów offshoringu (Offshore Financial Centre - OFC) było wynikiem przepływów kierowanych z rajów podatkowych oraz od podmiotów specjalnego przeznaczenia (Special Purposes Entities - SPE) [UNCTAD, 2015].

Opisane powyżej procesy doprowadziły na przestrzeni lat do zmiany struktury branżowej bezpośrednich inwestycji zagranicznych w sektorze usług. Na 
początku lat dziewięćdziesiątych XX w. w ówczesnej kompozycji dominowały działalność finansowa, a także handlowa, a ich udział w całkowitych zasobach BIZ w trzecim sektorze wyniósł $48 \%$ dla należności z tytułu działalności finansowej oraz 17\% z tytułu działalności handlowej. Z danych z 2007 r. wynika, że znaczenie tych dwóch branż zmniejszyło się w ciągu kilkunastu lat, choć nadal pozostało duże. Należności wynikające z inwestycji w sektorze finansowym stanowiły $33 \%$ całkowitych zasobów BIZ, a w sektorze handlowym - 10\% [UNTCAD, 2009a]. Rosnąca skala działań korporacji transnarodowych związanych z optymalizacją podatkową oraz nasilenie się offshoringu procesów biznesowych znalazły swoje odzwierciedlenie we wzroście znaczenia BIZ w branżach klasyfikowanych jako działalność biznesowa (business activities, klasyfikacja ONZ ISIC Rev. 3). W ramach tej działalności mieści się m.in. aktywność firm centralnych i holdingów ${ }^{1}$, a także działalność badawczo-rozwojowa, usługi call center oraz branża IT.

W analizowanym okresie udział należności z tytułu BIZ w działalność biznesową wzrósł trzykrotnie z 13\% do 37\%. Z kolei liberalizacja i deregulacja oraz procesy prywatyzacyjne na wielu rynkach usługowych znalazły odzwierciedlenie we wzroście znaczenia bezpośrednich inwestycji zagranicznych w takich branżach, jak: wytwarzanie i zaopatrywanie w energię elektryczną, gaz i wodę (wzrost udziału należności z 1\% w 1990 r. do 2\% w 2007 r.) oraz transport, gospodarka magazynowa i komunikacja (wzrost z 2\% do 7\%) [UNTCAD, 2009a].

\section{Bezpośrednie inwestycje zagraniczne Polski w sektorze usług}

O Polsce jako eksporterze BIZ można mówić dopiero od dziesięciu lat. Wcześniej, tj. od lat dziewięćdziesiątych XX w. do połowy pierwszej dekady XXI w. Polska była przede wszystkim odbiorcą zagranicznego kapitału bezpośredniego inwestowania. W tym okresie skala należności z tytułu polskich BIZ była znikoma i dominowały w nich głównie usługi, w tym działalność pośrednictwa pieniężnego, transport oraz działalność wspierająca eksport, jak handel, które w 1996 r. sta-

1 Działalność firm centralnych i holdingów klasyfikuje się jako „działalność biznesową”, ale działalność holdingów finansowych zalicza się do grupy „działalność finansowa”. Niektóre kraje działalność holdingów finansowych klasyfikują jednak jako działalność biznesową. Dane dostępne $\mathrm{w}$ raportach UNCTAD uniemożliwiają zejście na niższy poziom agregacji danych i tym samym przeprowadzenie analizy tego, na ile zmniejszenie się udziału należności z tytułu BIZ w sektorze finansów w całkowitych zasobach BIZ w trzecim sektorze było wynikiem zmian w aktywności holdingów finansowych, a na ile zmian $w$ innych branżach finansowych. Można jednak przyjąc, że inwestycje w działalność holdingów finansowych nie tylko nie zmniejszyły się, ale nawet wzrosły. Według danych za rok 2007 28\% należności z tytułu BIZ w działalność biznesową należało do Hongkongu, który działalność holdingów finansowych zalicza do działalności biznesowej. Ponadto, jak wynika z danych Eurostatu, w przypadku krajów unijnych skala bezpośrednich inwestycji zagranicznych w działalność holdingów finansowych jest duża. W latach 2010-2011 udział unijnych należności z tego tytułu wyniósł ponad 33\% [Eurostat]. 
nowiły blisko 93\% wartości polskich BIZ w trzecim sektorze, a w 2000 r. - 85\%. Przy tak znikomej wartości polskich BIZ duży udział w nich usług nie był odzwierciedleniem światowych tendencji rosnącego znaczenia usług w gospodarce, lecz głównie braku kapitału inwestycyjnego polskich przedsiębiorstw. Do początku XXI w. należności z tytułu BIZ w trzecim sektorze stanowiły większość polskich inwestycji.

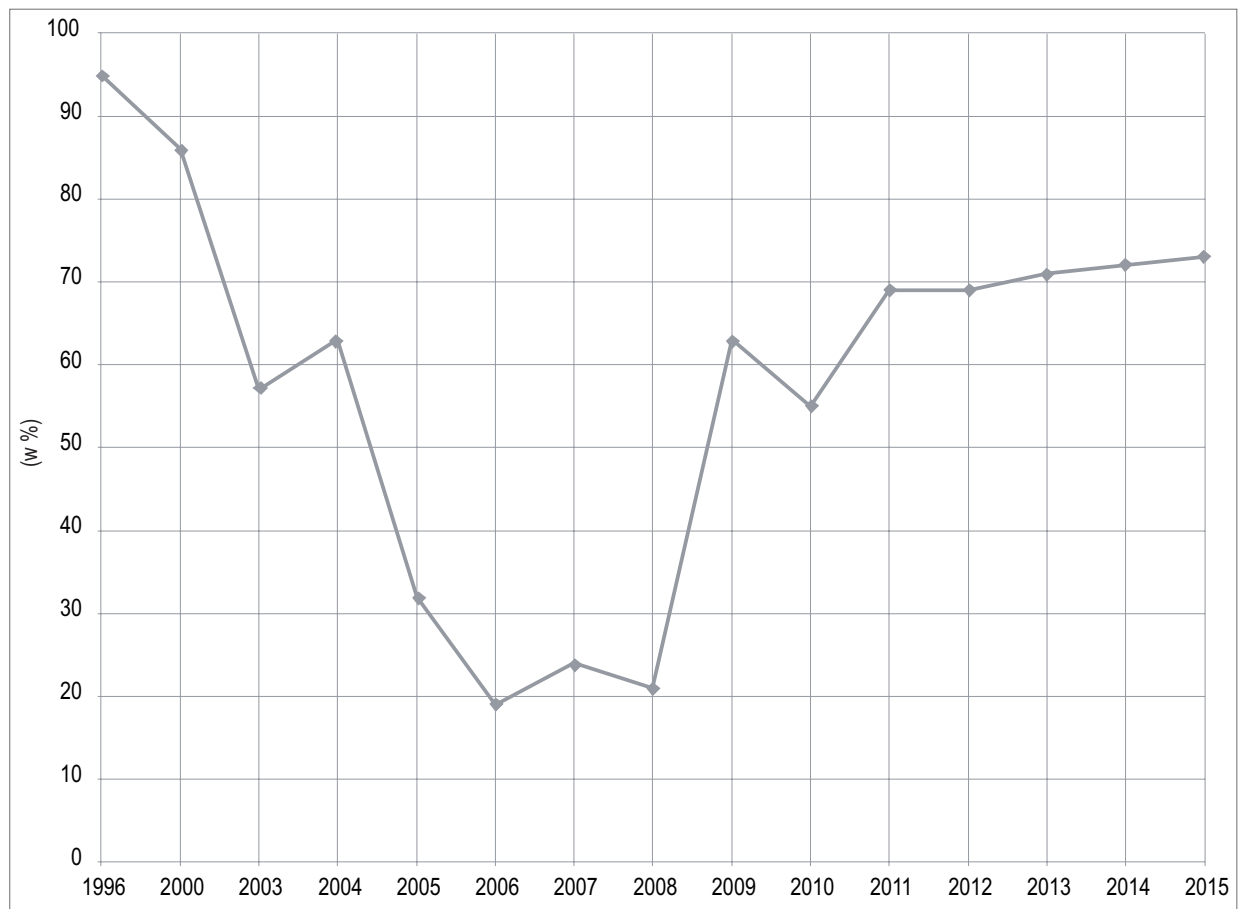

Rysunek 2. Udział należności z tytułu polskich BIZ w sektorze usług w łącznych należnościach Polski z tytułu BIZ

Źródło: Obliczenia własne na podstawie: [NBP, 2007; NBP, 2008a; NBP, 2008b; NBP, 2008c; NBP, 2009a; NBP, 2009b; NBP, 2009c; NBP, 2010a; NBP, 2010b; NBP, 2011; NBP, 2012; NBP, 2013; NBP, 2014; NBP, 2015].

Stopniowo jednak, wraz z rosnącą skalą bezpośrednich inwestycji polskich przedsiębiorstw poza granicami kraju, udział usług w strukturze polskich BIZ malał. Aktywność Polski jako bezpośredniego inwestora zagranicznego wzrosła wyraźnie po wejściu do Unii Europejskiej. Wypływ BIZ z Polski stawał się coraz bardziej znaczący, a kierowano je w dużej części do branż przetwórczych, w wyniku czego udział usług $\mathrm{w}$ strukturze należności z tytułu polskich bezpośrednich inwestycji zagranicznych malał, osiągając w 2006 r. poziom jedynie 19\%. Odwrócenie trendu nastąpiło w 2009 r., kiedy to udział usług w strukturze polskich BIZ 
wyniósł prawie 63\%. W kolejnych latach znaczenie trzeciego sektora w eksporcie polskiego kapitału inwestycyjnego rosło aż do ponad 72\% w 2015 r.

Analizując strukturę rozkładu polskich BIZ w sektorze usług na przestrzeni lat, można zauważyć kilka tendencji. Po pierwsze, w strukturze tej zdecydowanie zmniejszyło się znaczenie transportu, a jego udział w ostatnich latach był zbliżony do wskaźnika unijnych należności z tytułu BIZ w tej branży². W 2015 r. zmniejszyło się także znaczenie handlu detalicznego i hurtowego - dość gwałtownie spadł udział tego sektora w portfelu inwestycyjnym polskich podmiotów. Podkreślenia wymaga jednak fakt, że do 2014 r. udział tej branży w polskich BIZ w sektorze usług był nie tylko znaczący, ale i wyższy niż w przypadku unijnych należności z tytułu BIZ, co wskazuje, że część polskich inwestycji zagranicznych miała charakter wspierania eksportu. Zagraniczne inwestycje polskich przedsiębiorstw przeznaczane były na rozwój sieci sprzedaży odzieży, obuwia, mebli, wyposażenia wnętrz i materiałów budowlanych oraz sprzedaży paliw.

Tabela 1. Struktura należności z tytułu polskich BIZ w sektorze usługowym w podziale na wybrane rodzaje działalności przedsiębiorstw bezpośredniego inwestowania w latach 1996 i $2000(\mathrm{w} \%)$

\begin{tabular}{|l|c|c|}
\hline \multicolumn{1}{|c|}{ Rodzaj działalności } & 1996 & 2000 \\
\hline Usługi & 100,0 & 100,0 \\
\hline Handel i naprawy & 16,8 & 17,0 \\
\hline Transport, gospodarka magazynowa i łączność & 29,0 & 27,6 \\
\hline w tym: telekomunikacja & b.d. & 0,2 \\
\hline Pośrednictwo finansowe & 48,0 & 51,0 \\
\hline w tym: pozostałe pośrednictwo finansowe & b.d. & 8,86 \\
\hline $\begin{array}{l}\text { Obsługa nieruchomości, informatyka, nauka, wynajem maszyn i pozo- } \\
\text { stałe usługi związane z prowadzeniem działalności gospodarczej }\end{array}$ & 0,6 & 1,6 \\
\hline w tym: działalność związana z zarządzaniem holdingami & 0,1 & 0,95 \\
\hline
\end{tabular}

* Klasyfikacja działalności zgodna z klasyfikacją NACE rev. 1.1. Udział procentowy poszczególnych działalności odnosi się do łącznej wartości należności z tytułu polskich BIZ w sektorze usług.

Źródło: Opracowanie własne na podstawie: [NBP, 2009].

Gwałtowny spadek udziału tej branży w polskich BIZ kierowanych do trzeciego sektora w 2015 r. związany był z około trzykrotnym zmniejszeniem wartości należności z tytułu posiadanych akcji i udziałów. Oznaczało to wycofanie części polskiego kapitału z rynków zagranicznych. Spadek ten był także wynikiem blisko trzykrotnego zmniejszenia wartości należności z tytułu pożyczek wewnątrzkor-

2 W latach 2010-2014 udział transportu i gospodarki magazynowej w łącznych należnościach z tytułu unijnych BIZ wahał się w przedziale 1,1-1,6\%. Obliczenia własne na podstawie danych EUROSTAT. 
poracyjnych. Wiązało się to ze spłatą części zadłużenia zagranicznych spółek wobec polskich inwestorów i może oznaczać np. spłatę kredytów handlowych, które w przypadku podmiotów powiązanych kapitałowo także zaliczane są do bezpośrednich inwestycji zagranicznych.

Tabela 2. Struktura należności z tytułu polskich BIZ w sektorze usług w podziale na wybrane rodzaje działalności przedsiębiorstw bezpośredniego inwestowania w latach 2010-2015 (w \%)

\begin{tabular}{|l|r|r|r|r|r|c|}
\hline \multicolumn{1}{|c|}{ Rodzaj działalności } & 2010 & 2011 & 2012 & 2013 & 2014 & 2015 \\
\hline Usługi & 100 & 100 & 100 & 100 & 100 & 100 \\
\hline Handel G & 22,0 & 12,7 & 14,5 & 9,2 & 9,1 & 3,4 \\
\hline Transport i gospodarka magazynowa H & 2,1 & 1,8 & 2,0 & 1,5 & 1,7 & 3,0 \\
\hline Informacja i komunikacja J & $-6,7$ & 3,8 & $-1,9$ & $-8,5$ & $-15,2$ & $-11,2$ \\
\hline w tym: telekomunikacja J 61 & $-6,5$ & $-2,8$ & $-1,6$ & $-10,5$ & $-10,9$ & $-14,6$ \\
\hline Działalność finansowa i ubezpieczeniowa K & 34,8 & 37,2 & 43,6 & 59,3 & 69,6 & 70,5 \\
\hline w tym: holdingi finansowe K 64.2 & 7,5 & 12,5 & 17,8 & 40,7 & 53,9 & 51,3 \\
\hline $\begin{array}{l}\text { Działalność profesjonalna, naukowa } \\
\text { i techniczna M }\end{array}$ & 26,0 & 34,2 & 16,9 & 16,5 & 19,9 & 16,6 \\
\hline w tym: działalność firm centralnych M 70.1 & 3,7 & 8,2 & 8,0 & 10,6 & 13,5 & 9,5 \\
\hline
\end{tabular}

* Klasyfikacja działalności zgodna z klasyfikacją NACE rev. 2. Udział procentowy poszczególnych działalności odnosi się do łącznej wartości należności z tytułu polskich BIZ w sektorze usług.

Źródło: Opracowanie własne na podstawie: [NBP, 2010b; NBP, 2011; NBP, 2012; NBP, 2013; NBP, 2014; NBP, 2015].

Po drugie, przy śladowym eksporcie kapitału Polski do branży telekomunikacyjnej należy zwrócić uwagę na to, że od 2010 r. występują ujemne należności z tytułu polskich inwestycji w tej branży, które dodatkowo w latach 2014-2015 jeszcze istotnie się zwiększyły. Jest to wynik zadłużenia polskich inwestorów bezpośrednich w zagranicznych spółkach córkach i świadczy o tym, że polskie przedsiębiorstwa telekomunikacyjne, w których dominuje międzynarodowy kapitał inwestycyjny, pozyskują środki finansowe za pośrednictwem zagranicznych spółek zależnych.

Najważniejsza tendencja dotyczy jednak rosnącej skali działań polskich przedsiębiorstw związanych z optymalizacjami podatkowymi. Świadczy o tym gwałtowny wzrost polskich inwestycji zagranicznych w działalność finansową i ubezpieczeniową, a w szczególności holdingów finansowych, których udział w latach 2010-2015 wzrósł z 7,46\% do 51\% wartości polskich BIZ w usługach. Trend ten potwierdza także zwiększenie udziału działalności firm centralnych w polskich BIZ w sektorze usług z 3,7\% w 2010 r. do 9,5\% w 2015 r. Tak więc w 2015 r. ponad 60\% należności z tytułu polskich BIZ w sektorze usług związanych było $\mathrm{z}$ inwestycjami $\mathrm{w}$ działalność holdingów finansowych i zarządzających. 
Biorąc pod uwagę całkowite należności z tytułu polskich BIZ w 2015 r., inwestycje w holdingi stanowiły ponad $40 \%$ ich wartości.

Taka struktura branżowa zagranicznych inwestycji bezpośrednich polskich przedsiębiorstw w połączeniu ze strukturą ich geograficznego rozmieszczenia wskazuje, że podstawowym celem tej działalności jest minimalizowanie zobowiązań podatkowych podmiotów powiązanych kapitałowo. Większość należności z tytułu polskich BIZ skoncentrowana jest bowiem w krajach określanych jako centra finansowe. W latach 2013-2015 od 75\% do 84\% polskich należności z tytułu BIZ pochodziła z inwestycji w spółki cypryjskie, luksemburskie, holenderskie, szwajcarskie i brytyjskie.

W analizie zjawiska optymalizacji podatkowej należy uwzględnić fakt, że dużą część kapitału bezpośredniego inwestowania płynącego z Polski (ponad 60\% wartości) generują przedsiębiorstwa pozostające pod kontrolą zagranicznych podmiotów [NBP, 2012]. Polskie przedsiębiorstwa kontrolowane przez międzynarodowy kapitał inwestowały głównie w krajach wykorzystywanych do tworzenia tzw. wehikułów korporacyjnych. Były to Luksemburg, Wielka Brytania, Szwajcaria, Belgia oraz Holandia. Polskie spółki w tworzonej przez międzynarodowe korporacje strukturze holdingowej wykorzystywane są zatem jako jedno z ogniw w procesie międzynarodowej optymalizacji podatkowej. Polskie BIZ z dużym komponentem kapitału międzynarodowego nie są zatem wynikiem realizacji strategii polskich przedsiębiorstw, ale całej międzynarodowej grupy kapitałowej.

Polskie przedsiębiorstwa kontrolowane przez rezydentów w celu sprostania rosnącej konkurencji ze strony międzynarodowych korporacji transnarodowych również zaczęły wykorzystywać mechanizmy międzynarodowej optymalizacji podatkowej. Wprawdzie na liście głównych kierunków inwestycyjnych tych podmiotów znalazły się kraje niezaliczane do centrów finansowych, jednak także w ich przypadku kraje o korzystnych rozwiązaniach podatkowych (Cypr, Luksemburg) okazały się najważniejszymi destynacjami dla ich inwestycji bezpośrednich [NBP, 2012].

W rozważaniach na temat wykorzystania międzynarodowego mechanizmu minimalizowania obciążeń fiskalnych w ramach polskich BIZ należy uwzględnić także strukturę kapitałową tychże inwestycji.

W 2015 r. w przekazanym przez Polskę na rynki zagraniczne kapitale dominowały inwestycje $\mathrm{w}$ akcje i udziały oraz reinwestowane zyski zarówno w sektorze usług, jak i w przetwórstwie przemysłowym. Tym, co wyróżnia inwestycje w trzecim sektorze, są jednak ujemne należności z tytułu dłużnych instrumentów finansowych, które wynikają z zadłużania się polskich inwestorów w zagranicznych spółkach zależnych. W ten sposób za pośrednictwem spółek córek pozyskiwane mogą być środki na finansowanie działalności. Może to jednak świadczyć 
także o podejmowaniu działań związanych z redukcją zobowiązań podatkowych, np. o optymalizacji podatkowej przy wykorzystaniu finansowania polskich przedsiębiorstw metodą zwrotną. W przypadku polskiej spółki jej zagraniczni udziałowcy celowo nie zapewniają jej wystarczającego kapitału zakładowego dostosowanego do skali działalności tego podmiotu, co zmusza ją do pozyskania zewnętrznych źródeł finansowania, w tym przypadku od zagranicznych udziałowców. W tej sytuacji zwiększane są koszty uzyskania przychodów polskiego podmiotu, obniżana jest podstawa opodatkowania, a zyski wyprowadzane do kraju siedziby zagranicznych udziałowców, gdzie mogą być objęte niższą stopą podatkową, pod warunkiem obowiązywania odpowiednich umów o unikaniu podwójnego opodatkowania. Istnieją także inne metody wykorzystania pożyczek wewnątrzkorporacyjnych $\mathrm{w}$ celach zmniejszenia międzynarodowych obciążeń podatkowych [Nawrot, 2014].

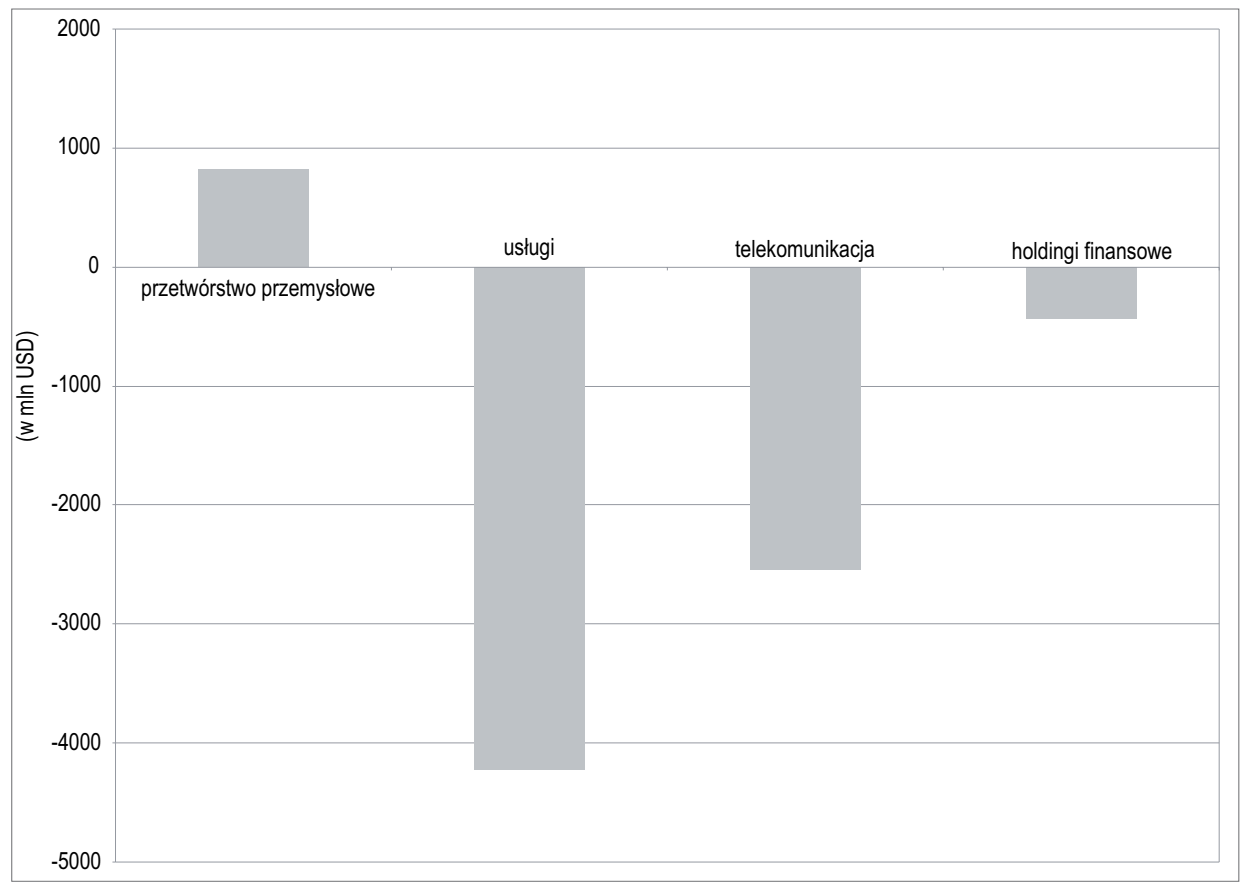

Rysunek 3. Należności Polski z tytułu BIZ w instrumenty dłużne w 2015 r. w wybranych sektorach

Źródło: Opracowanie własne na podstawie: [NBP, 2015].

W tym kontekście, patrząc na strukturę kapitałową polskich należności w poszczególnych branżach usługowych, można zauważyć, że największe ujemne zaangażowanie BIZ $\mathrm{w}$ instrumenty dłużne występuje $\mathrm{w}$ przypadku dwóch 
działalności: telekomunikacyjnej oraz finansowej i ubezpieczeniowej, w tym holdingów finansowych. W przypadku branży telekomunikacyjnej przy znikomych wręcz inwestycjach $\mathrm{w}$ akcje nieproporcjonalnie wysoka wartość ujemnych należności z tytułu kredytów wewnątrzkorporacyjnych wyraźnie wskazuje na wykorzystywanie pożyczek $w$ celach optymalizacji finansowych. Podobny charakter mają polskie BIZ $\mathrm{w}$ instrumenty dłużne $\mathrm{w}$ ramach holdingów finansowych.

\section{Podsumowanie}

Z danych na temat bezpośrednich inwestycji zagranicznych polskich przedsiębiorstw wynika, że udział sektora usług w aktywności inwestycyjnej polskich przedsiębiorstw jest obecnie duży, co pozostaje w zgodzie z trendami światowymi. W strukturze branżowej tych inwestycji dominuje działalność holdingów, co jednocześnie przy ich geograficznym skoncentrowaniu w centrach finansowych jednoznacznie wskazuje na cel tej aktywności, którym jest wykorzystanie międzynarodowych mechanizmów optymalizacji podatkowej. Czterdziestoprocentowy udział holdingów w całkowitych należnościach Polski z tytułu zainwestowanego kapitału poza granicami kraju oraz skupienie $84 \%$ łącznych polskich należności z tytułu BIZ w krajach o korzystnych rozwiązaniach prawnych umożliwiających obniżanie należności fiskalnych nie pozostawia wątpliwości co do rzeczywistych motywów inwestycyjnych dużej części podmiotów gospodarczych zarejestrowanych w Polsce.

Tak więc powodem zaangażowania w eksport kapitałów bezpośredniego inwestowania dużej grupy polskich przedsiębiorstw nie jest prowadzenie faktycznej działalności gospodarczej poza granicami kraju, ale obniżenie swoich zobowiązań fiskalnych. Zjawisko to dotyczy nie tylko polskich przedsiębiorstw znajdujących się pod kontrolą kapitału zagranicznego, ale także podmiotów kontrolowanych przez rezydentów. Nasilenie procesu optymalizacji fiskalnej dzięki wykorzystaniu podmiotów bezpośredniego inwestowania zauważalne jest zwłaszcza w ostatnich kilku latach.

Bibliografia

Dunning J.H., 1981, Explaining the International Direct Investment Position of Countries. Towards a Dynamic or Development Approach, Weltwirtschaftliches Archiv, vol. 117.

Dunning J.H., 1986, The investment development cycle revisited, Weltwirtschaftliches Archiv, vol. 122.

Dunning J.H., Narula R., 2002, The Investment Development Path Revisited, [w:] J.H. Dunning, Theories and Paradigms of International Business Activity. The Selected Essays of John H. Dunning, Edward Elgar, Cheltenham, UK - Northampton, MA. 
Eurostat, European direct invesments, http://ec.europa.eu/eurostat/data/database [dostęp: 25.03.2017].

Gereffi G., Fernandez-Stark K., 2010, The Offshore Services Global Value Chain, Center on Globalization, Governance \& Competitiveness, Duke University.

Gorynia M., Nowak J., Wolniak R., 2009, Poland's Investment Development Path. In search of a synthesis, International Journal of Economic Policy in Emerging Economies, vol. 2, no. 2.

Gorynia M., Nowak J., Wolniak R., 2010a, Foreign Direct Investment in Central and Eastern Europe. The IDB trajectories of selected countries, The Poznań University of Economics Review, vol. 10, no. 1 .

Gorynia M., Nowak J., Wolniak R., 2010b, Investment development paths of Central European Countries. A comparative analysis, Argumenta Oeconomica, vol. 1, no. 24.

Gorynia M., Nowak J., Wolniak R., 2012, Emerging Profiles of Polish Outward Foreign Direct Investment, Journal of East-West Business, vol. 18.

Nawrot R.A., 2014, Międzynarodowa optymalizacja podatkowa, Difin, Warszawa.

NBP, 2007, Polskie inwestycje bezpośrednie za granica w 2006 roku, Narodowy Bank Polski, Warszawa.

NBP, 2008a, Polskie inwestycje bezpośrednie za granica w 2004 roku. Aneks statystyczny, Narodowy Bank Polski, Warszawa.

NBP, 2008b, Polskie inwestycje bezpośrednie za granica w 2005 roku. Aneks statystyczny, Narodowy Bank Polski, Warszawa.

NBP, 2008c, Polskie inwestycje bezpośrednie za granica w 2007 roku, Narodowy Bank Polski, Warszawa.

NBP, 2009a, Polskie inwestycje bezpośrednie za granica w latach 1996-2002. Aneks statystyczny, Narodowy Bank Polski, Warszawa.

NBP, 2009b, Polskie inwestycje bezpośrednie za granica w 2003 roku. Aneks statystyczny, Narodowy Bank Polski, Warszawa.

NBP, 2009c, Polskie inwestycje bezpośrednie za granica w 2008 roku, Narodowy Bank Polski, Warszawa.

NBP, 2010a, Polskie inwestycje bezpośrednie za granica w 2009 roku. Aneks statystyczny, Narodowy Bank Polski, Warszawa.

NBP, 2010b, Polskie inwestycje bezpośrednie za granica - 2010, http://www.nbp.pl/home.aspx?f =/publikacje/pib/pib.html [dostęp: 30.03.2017].

NBP, 2011, Polskie inwestycje bezpośrednie za granica - 2011, http://www.nbp.pl/home.aspx?f $=/$ publikacje/pib/pib.html [dostęp: 30.03.2017].

NBP, 2012, Polskie inwestycje bezpośrednie za granica - 2012, http://www.nbp.pl/home.aspx?f =/publikacje/pib/pib.html [dostęp: 30.03.2017].

NBP, 2013, Polskie inwestycje bezpośrednie za granica - 2013, http://www.nbp.pl/home.aspx?f =/publikacje/pib/pib.html [dostęp: 30.03.2017].

NBP, 2014, Polskie inwestycje bezpośrednie za granica - 2014, http://www.nbp.pl/home.aspx?f =/publikacje/pib/pib.html [dostęp: 30.03.2017].

NBP, 2015, Polskie inwestycje bezpośrednie za granica - 2015, http://www.nbp.pl/home.aspx?f =/publikacje/pib/pib.html [dostęp: 30.03.2017].

Radło M.-J., Sass M., 2012, Outward Foreign Direct Investments and Emerging Multinationals from Central and Eastern Europe. The Case of Visegrad Countries, Eastern European Economics, vol. 50, no. 2 . 
UNCTAD, 1994, Liberalizing International Transactions in Services. A Handbook, UN, New YorkGeneva.

UNCTAD, 2002, Unctad Handbook of Statistics 2002, UN, New York - Geneva.

UNCTAD, 2004, World Investment Report 2004. The Shift Towards Services, UN, New YorkGeneva.

UNCTAD, 2009a, World Investment Report 2009. Transnational Corporations, Agricultural Production and Development, UN, New York - Geneva.

UNCTAD, 2009b, Unctad Handbook of Statistics 2009, UN, New York - Geneva.

UNCTAD, 2014, Unctad Handbook of Statistics 2014, UN, New York - Geneva.

UNCTAD, 2015, World Investment Report 2015. Reforming International Investment Governance, UN, New York - Geneva.

WTO, 2005, World Trade Report. Exploring the links between trade, standards and the WTO, WTO.

A. Stanowska-Hirsch (®) agnieszka.stanowska@post.pl Instytut Handlu Zagranicznego, Uniwersytet Gdański, ul. Armii Krajowej 119/121, 81-824 Sopot, Polska 